\title{
Perennial cereal crops: An initial evaluation of wheat derivatives grown in mixtures with a regenerating annual legume
}

\author{
Richard C. Hayes ${ }^{1 *}$, Matthew T. Newell ${ }^{2}$, Timothy E. Crews ${ }^{3}$ and Mark B. Peoples ${ }^{4}$ \\ 'NSW Department of Primary Industries, Wagga Wagga Agricultural Institute, Pine Gully Road, Wagga Wagga, \\ NSW 2650, Australia. \\ NSW DPI, Cowra Agricultural Research and Advisory Station, Binni Creek Rd, Cowra, NSW 2794, Australia. \\ ${ }^{3}$ The Land Institute, 2440 E. Water Well Rd., Salina, Kansas 67401, USA. \\ ${ }^{4}$ CSIRO Agriculture and Food, GPO Box 1600, Canberra, ACT 2601, Australia. \\ *Corresponding author: richard.hayes@dpi.nsw.gov.au
}

\begin{abstract}
A field experiment was established to test the impact on crop yield, total productivity and biological di-nitrogen $\left(\mathrm{N}_{2}\right)$ fixation of a self-regenerating annual legume, subterranean clover (Trifolium subterraneum L.), grown in mixtures with experimental perennial wheat lines. Legume content was altered in one intermediate wheatgrass (Thinopyrum intermedium (Host) Barkworth \& Dewey) and two wheat (Triticum aestivum L.) $\times$ wheatgrass (Th. spp.) hybrid-based stands by sowing the legume in the same drill row as the perennial crop, or in every second or third row, spatially separated from the perennial crop. The hybrid perennial crops were more vigorous than intermediate wheatgrass in year 1, competing strongly and reducing legume biomass over the $2 \mathrm{yr}$ period leading to reduced inputs of fixed nitrogen $(\mathrm{N})$. However, both hybrid crops declined to negligible levels following the first summer with only the intermediate wheatgrass persisting in adequate densities in year 2. Spatially separating the perennial crop from the legume in alternate drill rows increased legume biomass by $32-128 \%$ and clover regeneration by $31-195 \%$, and reduced weed incursion by up to $47 \%$ compared with where it was sown in mixed rows. However, spatial separation more than halved grain yields in year 2 compared with where the perennial crop was grown in every drill row. This likely reflected changed competition dynamics where the modified spatial configurations at sowing limited the perennial crops' access to resources. When estimates of the total inputs of fixed $\mathrm{N}$ from the clover $\left(5-165 \mathrm{~kg} \mathrm{~N} \mathrm{ha}^{-1}\right.$ in year 2) were compared with the amounts of $\mathrm{N}$ removed in grain by the different perennial wheat treatments $\left(10-55 \mathrm{~kg} \mathrm{~N} \mathrm{ha}^{-1}\right.$ in year 1), it appears feasible that a companion legume could fix sufficient $\mathrm{N}$ to maintain the $\mathrm{N}$ balance of a cropping system producing 1.5-2.0 $\mathrm{tgrain} \mathrm{ha}^{-1}$ each year. The inclusion of a legume increased total above-ground biomass by up to $142 \%$, particularly in year 2, but this did not translate into increased grain yields. It seems unlikely that a self-regenerating annual legume will be able to effectively coexist among a dense perennial wheat canopy where both species are sown in the same drill row. Further research is required to develop strategies to channel more of the additional resources apparently accessed by the companion legume into grain production.
\end{abstract}

Key words: subterranean clover, binary mixture, row configuration, nitrogen, competition, intermediate wheatgrass

\section{Introduction}

Previous reviews have described the vision for future grain production systems, which incorporate perennial crop species to reduce the reliance of agriculture on annual crops, and to redress the environmental degradation of agricultural landscapes (Crews and DeHaan, 2015; Crews et al., 2016). Environmental degradation arises from inherent phenological characteristics of annual crops such as their short life cycle resulting in reduced soil cover exposing soils to wind and water erosion, and a shallow rooting habit increasing the opportunity for movement of water and nutrients to below the plant root zone (Dunin and Passioura, 2006). However, degradation is also attributable to common management practices used in the cultivation of annual crops, such as tillage, excessive fertilizer use (Gomiero et al., 2011), and periods of fallow between crops increasing the 
vulnerability of soil to nitrogen $(\mathrm{N})$ and organic matter loss (Crews and Peoples, 2005).

To minimize the use of fertilizers, it has been proposed that non-leguminous perennial crops should be grown in mixtures with a $\mathrm{N}_{2}$-fixing legume to supply a proportion of the perennial crop's $\mathrm{N}$ requirements (Crews et al., 2016). This approach is analogous to practices widely employed in grazing systems whereby perennial forage grasses are commonly grown in a 'mixed' sward containing one or more legume species (Davies, 2001). While Crews et al. (2016) contend that it is theoretically possible to supply sufficient quantities of $\mathrm{N}$ through biological $\mathrm{N}_{2}$ fixation and other endogenous sources to meet much of the perennial crop's needs, the supply of $\mathrm{N}$ from the legume will depend upon factors such as the ability to reliably grow sufficient legume biomass to fix adequate quantities of N (Peoples et al., 2012), the efficiency of $\mathrm{N}$-transfer between legume and non-legume (PirhoferWalzl et al., 2012), and the ability to achieve a stable mixture of legumes and non-legumes through time (Davies, 2001). It remains unclear whether an intercrop of legumes and perennial grains might improve or reduce perennial crop production in the long-term. Inter-seeded legumes could compete with the perennial crop for space, water, light, and nutrient resources. On the other hand, previous studies have shown that pure stands have reduced resource-use efficiency compared with a mixture of multiple species (Jolliffe, 1997; Picasso et al., 2011). To date no field experimentation has been reported, which examines the performance of perennial wheat derivatives grown in mixtures with legumes.

Achieving stable mixtures of forage grasses and legumes is difficult largely due to interspecific competition between the sward components. Perennial forage grass swards grown in crop rotations often become grass-dominant with legume productivity quickly becoming insufficient to meet minimum N-demands of the perennial grass, much less the subsequent cropping phase (Dear et al., 1998, 1999, 2004). Novel approaches are required to enhance the stability of mixed swards, particularly if perennial cereal crops are to be grown in conjunction with legumes. Previous researchers (e.g., Harper, 1977; Boschma et al., 2010) have postulated that spatially separating legumes from non-legumes at sowing could be a way to reduce the interspecific competition between sward components and achieve a more stable mixture. Although various studies have taken this approach when establishing previous experiments (e.g., Wolfe and Southwood, 1980; Sleugh et al., 2000), few studies have evaluated the effect of alternative sowing configurations on sward productivity and composition (Sandral et al., 2015). Butler et al. (2011) demonstrated that alternating drill rows at sowing reduced interspecific competition of an establishing binary mixture of a perennial forage grass, tall fescue (Schedonerus arundinaceus Schreb.), and a perennial forage legume, alfalfa (lucerne; Medicago sativa L.), compared with swards where both species were sown in each drill row. Spatial separation of species may be required in order to maintain adequate legume density among a vigorous perennial crop canopy.

The current study is an initial examination of the response of three perennial wheatgrass-derived genotypes grown in mixtures with a legume over 2 successive years. The experiment was conducted in south-eastern Australia, where elite breeding lines of perennial wheat derivatives have been previously observed to persist for up to 4 years (Hayes et al., 2012; Larkin et al., 2014). The legume was a self-regenerating annual forage, subterranean clover (Trifolium subterraneum L.), with known adaptation to the target environment and a demonstrated capacity to fix large quantities of atmospheric $\mathrm{N}_{2}$ (Peoples et al., 2012). Features of subterranean clover, such as its prostrate, annual and cool season growth habit contrast that of alfalfa, potentially making it a more compatible species with a perennial wheat in this target environment. The experiment tested two hypotheses: (i) that perennial crop productivity can be maintained with the addition of an annual legume component and (ii) that the annual legume content is enhanced in a perennial crop binary mixture when components are spatially separated at sowing.

\section{Materials and Methods}

\section{Treatments}

A field experiment was sown on May 14, 2013 at the Cowra Agricultural Research and Advisory Station, NSW, Australia (S 33⒋211' E $148^{\circ} 42.236^{\prime}$, elevation $385 \mathrm{~m}$ ) and monitored over a $3 \mathrm{yr}$ period. Soil type at the site was a Red Chromosol (Isbell, 1996) with $\mathrm{pH}_{\mathrm{CaCl} 2}$ in the soil surface $0.10 \mathrm{~m}$ of 5.1. For several years prior to experimentation the site grew alfalfa for grazing. Initial soil cores taken to $1.2 \mathrm{~m}$ depth from across the site for characterization purposes indicated there to be $140-150 \mathrm{~kg}$ nitrate- $\mathrm{N} \mathrm{ha}{ }^{-1}$ in the soil profile, nearly $65 \%$ of which was observed in the surface $0.30 \mathrm{~m}$.

The experiment was a split-plot design replicated 3 times with plot dimensions of $7 \mathrm{~m} \times 4 \mathrm{~m}$. Main plots were sown to one of three perennial wheat-derived genotypes including two wheat (Triticum aestivum $\mathrm{L}$.) $\times$ wheatgrass (Thinopyrum spp.) hybrid entries, 11955 and CPI147235a (hereafter 235a), and the perennial intermediate wheatgrasss (Th. intermedium (Host) Barkworth \& Dewey), CPI-148055 (hereafter wheatgrass). More detail of the pedigree of these lines as well as their previous performance at this location is given in Hayes et al. (2012) and Larkin et al. (2014). Subplots included four row configuration treatments designed to alter the legume content of the perennial cereal swards; nil legume (perennial cereal only; Nil), legume and perennial cereal sown together in mixed rows (Mix), perennial cereals sown in alternate rows with the legume $\left(1_{\text {crop }}: 1_{\text {clover }}\right)$, and two rows 
of perennial cereal sown to every one row of legume $\left(2_{\text {crop }}: 1_{\text {clover }}\right)$.

The sowing rate $\left(\mathrm{kg} \mathrm{ha}^{-1}\right)$ of the cereals was calculated separately for each genotype to achieve a seedling density of 80 plants $\mathrm{m}^{-2}$. All treatments containing legume were sown with subterranean clover cv. Coolamon at a rate of $8 \mathrm{~kg} \mathrm{ha}^{-1}$ of pre-coated seed. The experiment was direct drilled with two passes of a cone seeder comprising 8 tynes set at a row spacing of $250 \mathrm{~mm}$ with narrow points and press wheels, delivering 16 drill rows per plot. The $1_{\text {crop }}: 1_{\text {clover }}$ treatment was achieved by condensing the number of rows into which seed of a particular species was drilled from 16 to 8 . The crop seed in the $2_{\text {crop }}: 1_{\text {clover }}$ treatment was condensed from 16 to 10 drill rows per plot and the clover was condensed to the remaining six rows. A mix of diammonium phosphate and superphosphate was broadcast across the experimental area immediately prior to sowing at rates calculated to deliver $22 \mathrm{~kg} \mathrm{P}, 14 \mathrm{~kg} \mathrm{~N}$ and $9 \mathrm{~kg} \mathrm{~S}$, per hectare.

\section{Seasonal conditions}

The long-term average annual rainfall at this site is $620 \mathrm{~mm}$ with a reasonably uniform monthly distribution. Higher temperatures in summer typically lead to less effective rainfall due to greater evaporation rates (Table 1). Annual rainfall during the experimental period was drier than average with 2013 and 2014 receiving 26 and 16\% less rainfall compared with the long-term average, respectively. Relatively little rainfall was received during the first summer (December 2013-February 2014) and average monthly maximum temperatures during this period were up to $2.5^{\circ} \mathrm{C}$ hotter than average. Late winter and spring rainfall in both years was generally close to half the long-term monthly average at that site (Table 1).

\section{Management and sampling}

The trial area was sprayed prior to sowing with $2 \mathrm{~L} \mathrm{ha}^{-1}$ of $135 \mathrm{~g} \mathrm{~L}^{-1}$ Paraquat $+115 \mathrm{~g} \mathrm{~L}^{-1}$ Diquat. Post emergent grass and broadleaf weeds were controlled with herbicides known to be relatively safe on wheat and subterranean clover; separate applications of $250 \mathrm{ml} \mathrm{ha}^{-1}$ of $100 \mathrm{~g} \mathrm{~L}^{-1}$ pinoxaden $+25 \mathrm{~g} \mathrm{~L}^{-1}$ cloquintocet-mexyl and $25 \mathrm{~g} \mathrm{ha}^{-1}$ of $800 \mathrm{~g} \mathrm{~kg}^{-1}$ flumetsulam plus $700 \mathrm{ml} \mathrm{ha}^{-1}$ of $200 \mathrm{~g} \mathrm{~L}^{-1}$ bromoxynil. Also, $1.81 \mathrm{ha}^{-1}$ of $340 \mathrm{~g} \mathrm{~L}^{-1} \mathrm{MCPA}+$ $80 \mathrm{~g} \mathrm{~L}^{-1}$ dicamba was applied to the nil legume treatments only, to remove any background legumes. A small amount of supplementary irrigation was applied to all plots during summer in year 1 using an overhead sprinkler system to assist perennial cereal survival. In year 2 the same herbicides were used for in-crop weed control as in year 1. A further $15 \mathrm{~kg} \mathrm{ha}^{-1} \mathrm{P}$ and $19 \mathrm{~kg} \mathrm{ha}^{-1} \mathrm{~S}$ was broadcast across the site in May 2014 in the form of single superphosphate.

Plant density was determined on 17 June in year 1 when the majority of seedlings had developed three leaves, by counting the number of perennial crop and legume seedlings in two randomly placed $0.5 \mathrm{~m} \times 0.5 \mathrm{~m}$ quadrats per plot. In the $2_{\text {crop }}: 1_{\text {clover }}$ treatment, establishment densities were determined by counting seedling number in two $0.50 \mathrm{~m} \times 0.75 \mathrm{~m}$ quadrats per plot such that each quadrat included two crop and 1 legume sowing row. Spring dry matter (DM) production in year 1 was assessed on October 30 by removing herbage within a $0.5 \mathrm{~m} \times 0.5 \mathrm{~m}$ quadrat randomly placed in each plot. Again a larger quadrat, $0.75 \mathrm{~m}$ wide, was used in the $2_{\text {crop }}: 1_{\text {clover }}$ treatment to ensure the sample area included two rows of perennial crop and one row of legume. Herbage was sorted into species, dried at $60^{\circ} \mathrm{C}$ for $72 \mathrm{~h}$ and weighed. Herbage samples were taken using the same technique in year 2 during summer (February 18), fall (May 8) and winter (July 22) to assess available biomass. Subterranean clover was not sampled during summer (February) because it had senesced. Following these DM samplings in year 2, the remaining herbage was grazed by sheep to approximately $1.0 \mathrm{tha}^{-1}$ of residual biomass. The hybrid wheat lines showed some reproductive physiology prior to grazing in fall and winter in year 2, such as elongated stems and flowering heads, consistent with previous performance at this site (Hayes et al., 2012). A final sampling of biomass in year 2 was timed according to flowering times of each perennial crop species which was November 4 for the wheatgrass hybrid 11955, November 13 for 235a and December 20 for wheatgrass. No grazing took place following the final sampling and perennial crops were left to develop through to grain harvest. Subterranean clover was not sampled at this time due to the fact it had already senesced, attributable to the drier than average spring conditions (Table 1).

Samples of subterranean clover and of perennial crops collected in October year 1 and July year 2 were retained for $\mathrm{N}$ analysis of shoot tissue. Only perennial crop samples were collected in the nil legume treatments. Samples were analyzed for $\mathrm{N}$ concentration $(\% \mathrm{~N})$ and ${ }^{15} \mathrm{~N}$ composition using automatic $\mathrm{N}$ and carbon analysis (ANCA-SL) interfaced to a 20-20 stable isotope mass spectrometer (Europa Scientific; Crewe, UK). The amounts of above-ground (shoot or herbage) $\mathrm{N}$ accumulated by the different treatments was calculated from measures of shoot DM and $\mathrm{N}$ concentrations as:

Shoot $\mathrm{N}=($ shoot dry matter $) \times(\% \mathrm{~N} / 100)$

The proportion of subterranean clover herbage $\mathrm{N}$ derived from $\mathrm{N}_{2}$ fixation was calculated using the natural ${ }^{15} \mathrm{~N}$ abundance method based on the ${ }^{15} \mathrm{~N}$ analysis of the subterranean clover and perennial crop samples, and glasshouse-derived determinations of the ${ }^{15} \mathrm{~N}$ composition of shoots of subterranean clover grown with $\mathrm{N}_{2}$ as the sole source of N (Unkovich et al., 2008). The perennial crop in each treatment was assumed to provide a measure of the ${ }^{15} \mathrm{~N}$ composition of the plant-available soil $\mathrm{N}$. Estimations of the contribution of below-ground $\mathrm{N}$ 
Table 1. Long-term average (LAR) and monthly rainfall $(\mathrm{mm})$, and long-term average minimum and maximum temperatures $\left({ }^{\circ} \mathrm{C}\right)$ at the Cowra site compared with the experimental period.

\begin{tabular}{|c|c|c|c|c|c|c|c|c|c|c|c|c|c|}
\hline Year & Jan & Feb & Mar & Apr & May & Jun & Jul & Aug & Sep & Oct & Nov & Dec & Annual \\
\hline & \multicolumn{13}{|c|}{ Rainfall (mm) } \\
\hline 2013 & 8 & 33 & 74 & 1 & 22 & 118 & 42 & 22 & 34 & 22 & 53 & 35 & 463 \\
\hline 2014 & 11 & 20 & 103 & 50 & 34 & 55 & 34 & 26 & 34 & 34 & 17 & 72 & 520 \\
\hline 2015 & 73 & 8 & 5 & 105 & 40 & 20 & - & - & - & - & - & - & - \\
\hline \multirow[t]{2}{*}{ LAR } & 58 & 49 & 48 & 42 & 46 & 52 & 52 & 51 & 51 & 57 & 53 & 58 & 623 \\
\hline & \multicolumn{13}{|c|}{ Minimum temperature $\left({ }^{\circ} \mathrm{C}\right)$} \\
\hline 2013 & 17.0 & 16.0 & 13.5 & 7.2 & 4.4 & 5.2 & 2.8 & 3.2 & 4.2 & 4.6 & 9.3 & 13.1 & 8.4 \\
\hline 2014 & 16.2 & 17.0 & 14.5 & 10.1 & 5.4 & 4.8 & 1.6 & 1.1 & 2.7 & 6.1 & 11.4 & 15.0 & 8.8 \\
\hline 2015 & 16.3 & 16.2 & 12.3 & 10.4 & 5.9 & 2.3 & - & - & - & - & - & - & - \\
\hline \multirow[t]{2}{*}{ LAR } & 16.8 & 16.3 & 13.1 & 8.5 & 4.3 & 3.7 & 2.4 & 2.4 & 3.9 & 6.6 & 11.4 & 14.2 & 8.6 \\
\hline & \multicolumn{13}{|c|}{ Maximum temperature $\left({ }^{\circ} \mathrm{C}\right)$} \\
\hline 2013 & 36.1 & 31.6 & 28.3 & 24.7 & 19.4 & 15.2 & 15.4 & 15.8 & 21.5 & 24.9 & 27.4 & 31.9 & 24.3 \\
\hline 2014 & 34.4 & 32.7 & 27.4 & 23.0 & 19.5 & 15.0 & 14.1 & 16.3 & 20.1 & 26.4 & 31.3 & 31.4 & 24.3 \\
\hline 2015 & 30.9 & 32.7 & 29.4 & 21.9 & 17.5 & 15.1 & - & - & - & - & - & - & - \\
\hline LAR & 33.5 & 31.2 & 28.2 & 23.5 & 19.1 & 15.1 & 14.2 & 16.2 & 20.0 & 24.0 & 27.9 & 30.5 & 23.7 \\
\hline
\end{tabular}

to the total $\mathrm{N}$ of subterranean clover were calculated by multiplying the clover shoot $\mathrm{N}$ data by a root factor of 1.72 representing the equivalent of $42 \%$ of the total plant $\mathrm{N}$ being associated with nodulated roots (McNeill et al., 1997; Unkovich et al., 2010; Peoples et al., 2012). Total amounts of $\mathrm{N}_{2}$ fixed in the various treatments were subsequently calculated as:

$$
\begin{aligned}
\text { Total } \mathrm{N} \text { fixed }= & (\text { clover shoot } \mathrm{N} \times 1.72) \\
& \times(\% \text { clover } \mathrm{N} \text { fixed } / 100)
\end{aligned}
$$

All plots were harvested for grain in years 1 and 2 when individual genotypes were considered mature. For the two wheatgrass hybrid entries this occurred in the third week of December in both years; the wheatgrass treatment was harvested 5 weeks later during the final week of January in both years. Samples were taken for the calculation of harvest index by cutting all perennial crop biomass at the soil surface from two randomly placed $0.5 \mathrm{~m} \times$ $0.5 \mathrm{~m}$ quadrats per plot, or two $0.50 \mathrm{~m} \times 0.75 \mathrm{~m}$ quadrats per plot in the 2:1 treatment. The remainder of the plots were harvested with a small plot header shortly after quadrat cuts were taken, and the weight of grain recorded for each plot. Harvest data from only the harvest index cuts are presented. Stubble and grain components from the harvest index samples were ground to $<2 \mathrm{~mm}$ and sub samples tested for $\mathrm{N}$ content following LECO combustion. Protein content of these samples was calculated by multiplying $\% \mathrm{~N} \times 5.7$ (AOCS, 1995). All trash from the harvesting operation was collected and removed to minimize the emergence of volunteer cereal seedlings in plots.

Subterranean clover regeneration was assessed in autumn in years 2 and 3 by counting the number of seedlings in two randomly selected $0.250 \mathrm{~m}^{2}$ areas, or in the case of the $2_{\text {crop }}: 1_{\text {clover }}$ treatment, two $0.375 \mathrm{~m}^{2}$ areas per plot. Basal frequency of the cereals was assessed at the same time by placing two $0.9 \mathrm{~m} \times 1.0 \mathrm{~m}$ quadrats, divided into $0.1 \mathrm{~m} \times 0.1 \mathrm{~m}$ squares, on each plot and counting the number of squares containing the base of a perennial crop plant. Basal frequency is an accepted method of non-destructively monitoring density of perennial species such as alfalfa beyond year 1 when it is impossible to visually determine the number of individuals comprising an alfalfa crown (Lodge and Gleeson, 1984). The initial measure of basal frequency was taken in year 1 at the same time seedling establishment density was determined. Values from each quadrat were summed, and expressed as a percentage.

\section{Statistical analysis}

Analyses of variance were conducted with a replicate + replicate.mainplot blocking structure, and a crop*row configuration treatment structure (Genstat version 17; VSN International Ltd). Analysis of the clover herbage $\mathrm{N}$ content data excluded the nil legume treatment in the analysis as this treatment was not sampled. Each sampling of the same variable was analyzed independently. Data were in transformed where it was necessary to normalize the distribution of data and residuals, and this usually occurred with data collected in year 2 where density of perennials in some treatments had declined to very low levels. Transformed data were back-transformed for presentation, and can be identified by the presence of a superscript letter in place of a determination of the least significant difference (1.s.d.). All data were analyzed at the $95 \%$ significance level $(P<0.05)$.

\section{Results}

A significant $(P<0.05)$ perennial crop $\times$ row configuration interaction existed for perennial crop density throughout the experiment (Table 2). All perennial 
Table 2. Crop establishment density (plants $\mathrm{m}^{-2}$ ) and basal frequency $(\%)$ in the 3 years of experimentation when grown as a nil legume or in combination with subterranean clover in mixed rows (Mix), in alternate rows $\left(1_{\text {crop }}: 1_{\text {clover }}\right)$ or in a ratio of 2 rows of perennial crop: 1 row of clover $\left(2_{\text {crop }}: 1_{\text {clover }}\right)$.

\begin{tabular}{|c|c|c|c|c|c|}
\hline \multirow[b]{2}{*}{$\begin{array}{l}\text { Perennial } \\
\text { crop }\end{array}$} & & \multicolumn{4}{|c|}{ Row configuration } \\
\hline & & $2_{\text {crop }}: 1_{\text {clover }}$ & $1_{\text {crop }}: 1_{\text {clover }}$ & Mix & $\begin{array}{l}\text { Nil } \\
\text { legume }\end{array}$ \\
\hline & & \multicolumn{4}{|c|}{ Establishment (plants $\mathrm{m}^{-2}$ ) } \\
\hline Wheatgrass & & 48 & 37 & 69 & 57 \\
\hline 11955 & & 71 & 82 & 99 & 93 \\
\hline \multirow[t]{3}{*}{$235 \mathrm{a}$} & & 69 & 69 & 85 & 87 \\
\hline & l.s.d.0.05 & & \multicolumn{3}{|c|}{9.6} \\
\hline & & \multicolumn{4}{|c|}{ Year 1 basal frequency $(\%)$} \\
\hline Wheatgrass & & 24 & 14 & 32 & 25 \\
\hline 11955 & & 27 & 19 & 38 & 37 \\
\hline \multirow[t]{3}{*}{$235 \mathrm{a}$} & & 28 & 19 & 37 & 36 \\
\hline & \multirow[t]{2}{*}{ l.s.d.0.05 } & \multicolumn{4}{|c|}{3.0} \\
\hline & & \multicolumn{4}{|c|}{ Year 2 basal frequency $(\%)$} \\
\hline Wheatgrass & & 23 & 16 & 27 & 24 \\
\hline 11955 & & 6 & 4 & 3 & 4 \\
\hline \multirow[t]{3}{*}{$235 \mathrm{a}$} & & 2 & 3 & 1 & 3 \\
\hline & \multirow{2}{*}{ l.s.d.0.05 } & \multicolumn{4}{|c|}{3.7} \\
\hline & & Year 3 basa & frequency ( & $\%)$ & \\
\hline Wheatgrass & & $21^{\mathrm{a}}$ & $20^{\mathrm{a}}$ & $17^{\mathrm{a}}$ & $22^{\mathrm{a}}$ \\
\hline 11955 & & $0^{\mathrm{bc}}$ & $4^{\mathrm{ab}}$ & $0^{\mathrm{c}}$ & $1^{\mathrm{ab}}$ \\
\hline $235 \mathrm{a}$ & & $0^{\mathrm{bc}}$ & $3^{\mathrm{ab}}$ & $1^{\mathrm{ab}}$ & $0^{\mathrm{c}}$ \\
\hline
\end{tabular}

Values followed by a superscript letter have been back-transformed; values followed by the same letter are not significantly different at $P=0.05$.

crops established at higher densities in the mixed or nil legume treatments compared with the $2_{\text {crop }}: 1_{\text {clover }}$ or $1_{\text {crop }}: 1_{\text {clover }}$ treatments. The wheatgrass established at lower densities than either of the hybrid treatments. However, the basal frequency of the hybrid perennial crops declined to negligible levels $(<5 \%)$ following the first summer, significantly lower than neighboring wheatgrass treatments (16-27\%). By year 3 there was no significant difference in basal frequency of the wheatgrass treatments due to sowing configuration (17-22\%).

No significant $(P>0.05)$ perennial crop $\times$ row configuration interaction existed for subterranean clover establishment or regeneration densities (Table 3). Establishment density of subterranean clover in year 1 was unaffected by perennial crop treatment, and was significantly higher in the mix treatments where subterranean clover was sown in every row compared with where it was sown only in every third row $\left(2_{\text {crop }}: 1_{\text {clover }}\right)$. There was no subterranean clover detected in the nil legume treatments in the establishment year. The combined density of wheat and subterranean clover in year 1 was highest in the mix treatments $\left(141\right.$ plants $\left.\mathrm{m}^{-2}\right)$, followed by $1_{\text {crop }}: 1_{\text {clover }}$ (113), $2_{\text {crop }}: 1_{\text {clover }}(103)$ and nil legume $(79 ; P<0.05$, 1.s. d. $=16.31)$. Subsequent subterranean clover regeneration
Table 3. Effect of perennial crop and row configuration treatments on the emergence of subterranean clover $\left(\right.$ plants $\mathrm{m}^{-2}$ ) in the 3 years of experimentation.

\begin{tabular}{|c|c|c|c|c|}
\hline \multicolumn{2}{|l|}{ Treatment } & Year 1 & Year 2 & Year 3 \\
\hline & & \multicolumn{3}{|c|}{ Perennial crop effect } \\
\hline Wheatgrass & & 39 & 141 & 552 \\
\hline 11955 & & 39 & 29 & 356 \\
\hline \multirow[t]{4}{*}{$235 \mathrm{a}$} & & 32 & 121 & 560 \\
\hline & $P$-value & 0.48 & $<0.001$ & 0.07 \\
\hline & l.s.d.0.05 & $n s$ & 40.1 & $n s$ \\
\hline & & \multicolumn{3}{|c|}{ Row configuration effect } \\
\hline $2_{\text {crop }}: 1_{\text {clover }}$ & & 40 & 79 & 640 \\
\hline $1_{\text {crop }}: 1_{\text {clover }}$ & & 50 & 230 & 743 \\
\hline Mix & & 56 & 78 & 566 \\
\hline \multirow[t]{3}{*}{ Nil legume } & & 0 & 0 & 21 \\
\hline & $P$-value & $<0.001$ & $<0.001$ & $<0.001$ \\
\hline & l.s.d.0.05 & 15 & 46 & 214 \\
\hline
\end{tabular}

Non-significant differences at $P=0.05$ are marked 'ns'.

was lower in the treatments sown to the hybrid perennial crop, 11955, than the remaining perennial crop treatments, and highest in the alternate row $\left(1_{\text {crop }}: 1_{\text {clover }}\right)$ treatment. Subterranean clover regeneration remained low in the nil legume treatments throughout the $2 \mathrm{yr}$ period indicating that pre-existing seed reserves were low across the site prior to the establishment of experimental treatments.

Year 1 above-ground perennial crop biomass was, on average, $35 \%$ greater in the 11955 treatments compared with the 235a treatment, and 6-fold greater compared with wheatgrass. Year 1 biomass of all perennial crops was lowest in the alternate row configuration $\left(1_{\text {crop }}: 1_{\text {clover }}\right)$ and generally higher in the nil legume treatments (Table 4). There was no significant $(P>0.05)$ perennial crop $\times$ sowing configuration interaction in year 2 spring perennial crop biomass, but significant main effects were observed where wheatgrass was the most productive perennial crop, and the nil legume $\left(2.36 \mathrm{tha}^{-1}\right)$ and mix (1.76) treatments were more productive than the $2_{\text {crop }}: 1_{\text {clover }}(1.16)$ and $1_{\text {crop }}: 1_{\text {clover }}(0.69)$ treatments (Table 4). Subterranean clover biomass was consistently higher in the $1_{\text {crop }}: 1_{\text {clover }}$ treatments, yielding $32 \%, 126$ and $128 \%$ more in spring year 1 , fall and winter year 2 , respectively, compared with where it was sown in mixed rows. Clover biomass was generally lowest in the 11955 treatments where crop biomass was greatest, and was almost negligible when sown with 11955 in mixed rows.

Total above-ground biomass (i.e., the sum of measured subterranean clover, perennial crop and weed dry matter) was significantly less in the nil legume treatment in the wheatgrass plots only in year 1 , but in year 2 all nil legume treatments were less productive swards. At the final sampling of biomass in winter of year 2, total biomass in the mix, $1_{\text {crop }}: 1_{\text {clover }}$ and $2_{\text {crop }}: 1_{\text {clover }}$ treatments were 52, 142 and $59 \%$ greater, respectively, compared with the nil legume plots $\left(1.2 \mathrm{tha}^{-1}\right)$. Weeds 
Table 4. Perennial crop $\times$ row arrangement interactions on seasonal measures of perennial crop and legume herbage production $\left(\mathrm{tha}^{-1}\right)$ and determinations of weed incursion ( $\%$ of total biomass) during the experimental period.

\begin{tabular}{|c|c|c|c|c|c|}
\hline \multirow[b]{2}{*}{ Perennial crop } & & \multicolumn{4}{|c|}{ Row configuration } \\
\hline & & $2_{\text {crop }}: 1_{\text {clover }}$ & $\mathbf{1}_{\text {crop }}: \mathbf{1}_{\text {clover }}$ & Mix & Nil legume \\
\hline \multicolumn{6}{|c|}{ Perennial crop; spring year 1} \\
\hline Wheatgrass & & 1.97 & 1.29 & 1.61 & 1.91 \\
\hline 11955 & & 9.57 & 9.13 & 10.96 & 11.51 \\
\hline $235 \mathrm{a}$ & & 6.82 & 6.55 & 7.65 & 9.56 \\
\hline \multicolumn{6}{|c|}{ l.s.d.0.05 } \\
\hline \multicolumn{6}{|c|}{ Subterranean clover; spring year 1} \\
\hline Wheatgrass & & 1.78 & 2.48 & 2.08 & 0.00 \\
\hline 11955 & & 1.03 & 0.44 & 0.07 & 0.00 \\
\hline $235 \mathrm{a}$ & & 1.93 & 1.52 & 0.51 & 0.00 \\
\hline \multicolumn{6}{|c|}{ l.s.d.0.05 } \\
\hline \multicolumn{6}{|c|}{ Percentage weed biomass; spring year 1} \\
\hline Wheatgrass & & 12 & 14 & 10 & 18 \\
\hline 11955 & & 3 & 2 & 2 & 2 \\
\hline $235 \mathrm{a}$ & & 6 & 7 & 6 & 2 \\
\hline \multicolumn{6}{|c|}{ 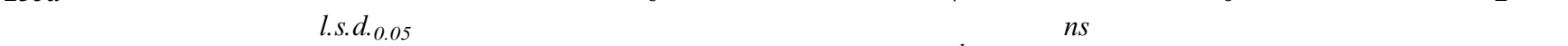 } \\
\hline \multicolumn{6}{|c|}{ Perennial crop; summer year $1^{l}$} \\
\hline Wheatgrass & & 0.33 & 0.66 & 0.53 & 0.71 \\
\hline 11955 & & 1.14 & 0.72 & 0.43 & 1.11 \\
\hline $235 \mathrm{a}$ & & 0.27 & 0.58 & 0.16 & 0.23 \\
\hline \multicolumn{6}{|c|}{ l.s.d.0.05 } \\
\hline \multicolumn{6}{|c|}{ Perennial crop; autumn year 2} \\
\hline Wheatgrass & & 1.88 & 2.24 & 1.86 & 2.67 \\
\hline 11955 & & 0.48 & 0.40 & 0.37 & 0.64 \\
\hline $235 \mathrm{a}$ & & 0.14 & 0.32 & 0.19 & 0.26 \\
\hline \multicolumn{6}{|c|}{0.406} \\
\hline \multicolumn{6}{|c|}{ Subterranean clover; autumn year 2} \\
\hline Wheatgrass & & 0.45 & 0.89 & 0.49 & 0.00 \\
\hline 11955 & & 0.33 & 0.63 & 0.03 & 0.00 \\
\hline $235 \mathrm{a}$ & & 1.16 & 1.62 & 0.86 & 0.01 \\
\hline \multicolumn{6}{|c|}{ l.s.d.0.05 } \\
\hline \multicolumn{6}{|c|}{ Percentage weed biomass; autumn year 2} \\
\hline Wheatgrass & & 7 & 4 & 9 & 7 \\
\hline 11955 & & 58 & 40 & 80 & 70 \\
\hline $235 \mathrm{a}$ & & 41 & 25 & 48 & 78 \\
\hline \multicolumn{6}{|c|}{ l.s.d.0.05 } \\
\hline \multicolumn{6}{|c|}{ Perennial crop; winter year 2} \\
\hline Wheatgrass & & 0.92 & 0.56 & 0.57 & 0.70 \\
\hline 11955 & & 0.13 & 0.26 & 0.13 & 0.18 \\
\hline $235 \mathrm{a}$ & & 0.09 & 0.18 & 0.16 & 0.12 \\
\hline \multicolumn{6}{|c|}{0.221} \\
\hline \multicolumn{6}{|c|}{ Subterranean clover; winter year 2} \\
\hline Wheatgrass & & 0.67 & 1.84 & 1.29 & 0.01 \\
\hline 11955 & & 1.22 & 1.27 & 0.21 & 0.12 \\
\hline $235 \mathrm{a}$ & & 1.44 & 3.58 & 1.43 & 0.04 \\
\hline & l.s.d.0.05 & \multicolumn{4}{|c|}{0.88} \\
\hline & & Percentage & ; winter yea & & \\
\hline Wheatgrass & & 8 & 3 & 2 & 9 \\
\hline 11955 & & 37 & 29 & 69 & 66 \\
\hline $235 \mathrm{a}$ & & 24 & 10 & 41 & 90 \\
\hline & l.s.d.0.05 & & & & \\
\hline
\end{tabular}


Table 4. (Cont.)

Row configuration

\begin{tabular}{|c|c|c|c|c|}
\hline Perennial crop & $\mathbf{2}_{\text {crop }}: 1_{\text {clover }}$ & $1_{\text {crop }}: 1_{\text {clover }}$ & Mix & Nil legume \\
\hline \multicolumn{5}{|c|}{ Perennial crop; spring year 2} \\
\hline Wheatgrass & 2.10 & 1.09 & 2.64 & 3.18 \\
\hline 11955 & 0.89 & 0.68 & 1.75 & 2.37 \\
\hline $235 \mathrm{a}$ & 0.49 & 0.31 & 0.88 & 1.54 \\
\hline & \multicolumn{4}{|c|}{$n s$} \\
\hline
\end{tabular}

${ }^{1}$ Weed incursion at this sampling date was negligible $\left(0.1 \mathrm{t} \mathrm{ha}^{-1}\right)$ and is not reported.

comprised $13 \%$ of total above-ground biomass in the wheatgrass treatment in year 1 , which was significantly $(P<0.01)$ greater than in either the $11955(2 \%)$ or $235 \mathrm{a}$ $(5 \%)$ treatments, but there was no significant effect of row configuration on weed content in year 1 (average $7 \%$; data not shown). There was no effect of perennial crop or row configuration treatment on weed content at the end of the first summer (average 20\%), but in the fall of year 2 weeds comprised a significantly $(P<$ $0.001)$ lower percentage of total above-ground biomass in the wheatgrass $(7 \%)$ plots compared with the $235 \mathrm{a}$ $(48 \%)$ and $11955(62 \%)$ treatments (1.s.d.0.05 $=11.2)$. The nil legume treatments at this sampling also comprised a higher percentage of weeds $(52 \%)$ compared with the $\operatorname{mix}(45 \%), 2_{\text {crop }}: 1_{\text {clover }}(35 \%)$, and $1_{\text {crop }}: 1_{\text {clover }}(23 \%)$ configurations (1.s.d.0.05 $=12.9$ ). A very similar pattern of weed incursion was also observed in the winter sampling of year 2 (data not shown).

There was no significant $(P>0.05)$ perennial crop $\times$ row configuration interaction in the grain yield data from either year. Grain yields in year 1 were $21 \%$ and 7 fold higher in the 11955 treatment compared with the $235 \mathrm{a}$ and wheatgrass treatments, respectively (Table 5). Grain protein and kernel size was significantly less in the wheatgrass compared with the hybrid perennial crops, but the $\mathrm{N}$ concentration of stubble was higher in the wheatgrass treatments. There was no effect of sowing configuration on yields or grain attributes in year 1 despite there being a greater number of tillers in the mix and nil legume treatments. Grain yields in year 2 were very low $\left(<280 \mathrm{~kg} \mathrm{ha}^{-1}\right)$, being highest in the 11955 and lowest in the wheatgrass treatments, and highest in the mixed and nil legume treatments compared with the other spatial configurations. There was no difference in grain protein between the different perennial crops in year 2 at $P=0.05$, although there were marked differences in grain size with grain from the hybrid perennial crops 4-6 fold greater compared with the wheatgrass. The wheatgrass stubble $\% \mathrm{~N}$ was almost double $(1.77 \%)$ that of the average of the hybrid perennial crops $(0.95 \%)$. Grain protein in year 2 was significantly lower and harvest index higher in the nil legume treatments. However, there was no significant difference in kernel size between row configurations. Nitrogen concentration of stubble was also lowest in the nil legume treatments and highest in the $2_{\text {crop }}: 1_{\text {clover }}$ treatments (Table 5).

There was a significant $(P<0.01)$ negative correlation $\left(R^{2}=0.44\right)$ between subterranean clover biomass and clover shoot $\mathrm{N}$ concentration in spring year 1 , but no relationship was apparent in year 2 (Fig. 1). In year 2 there was no significant difference in subterranean clover herbage $\% \mathrm{~N}$ between treatments (Table 6). Clover's reliance upon $\mathrm{N}_{2}$-fixation for growth was substantially greater in year $2(63-86 \%)$ than year 1 (17-38\%), but was not affected by either perennial crop or row configuration treatment in either year. Not surprisingly this greatly influenced the estimates of the total amounts of $\mathrm{N}_{2}$ fixed in each year $\left(1-21 \mathrm{~kg} \mathrm{~N}^{-1}\right.$ in year 1 cf 5-165 $\mathrm{kg} \mathrm{N} \mathrm{ha}^{-1}$ in year 2; Table 6) except for treatments where clover growth had been suppressed in mixed rows with 11955.

Perennial crop $\mathrm{N}$ concentration during the spring of year 1 was significantly $(P<0.05)$ greater in the wheatgrass herbage (average $2.18 \%$ ) compared with the hybrid perennial crops (average 1.54\%). There was no difference attributable to row configuration in that year (Table 7). In year 2, $\mathrm{N}$ concentrations were generally lower in the shoots of 11955 compared with the other perennial crops. Wheatgrass shoot $\mathrm{N}$ concentrations were lowest in the nil legume treatment compared with where it was grown alongside subterranean clover. Calculated $\mathrm{N}$ accumulation in above-ground perennial crop biomass in year 1 was greatest in the 11955 hybrid, and also greatest in the nil legume treatments. The percentage of total $\mathrm{N}$ partitioned in grain was higher in 11955 (45\%) compared with the $235 \mathrm{a}(38 \%)$ and wheatgrass treatments (24\%). Nitrogen accumulation in year 2 above-ground biomass was substantially less in most treatments compared with year 1 values. Wheatgrass stubble values were similar between years (32 and $37 \mathrm{~kg} \mathrm{ha}^{-1}$, respectively), but very little $\mathrm{N}$ was harvested in wheatgrass grain in year 2 (Table 8).

\section{Discussion}

\section{Perennial crop productivity}

The wheat $\times$ wheatgrass hybrids, 235a and 11955, were more vigorous in year 1 and had higher grain yields and 
Table 5. Effect of perennial crop and row configuration on grain yield $\left(\mathrm{kg} \mathrm{ha}^{-1}\right)$, grain protein $(\%)$, tiller number $\left(\mathrm{m}^{-2}\right)$, harvest index (HI), thousand kernel weight (TKW; g) and stubble $\mathrm{N}$ content (\%) at crop maturity in years 1 and 2.

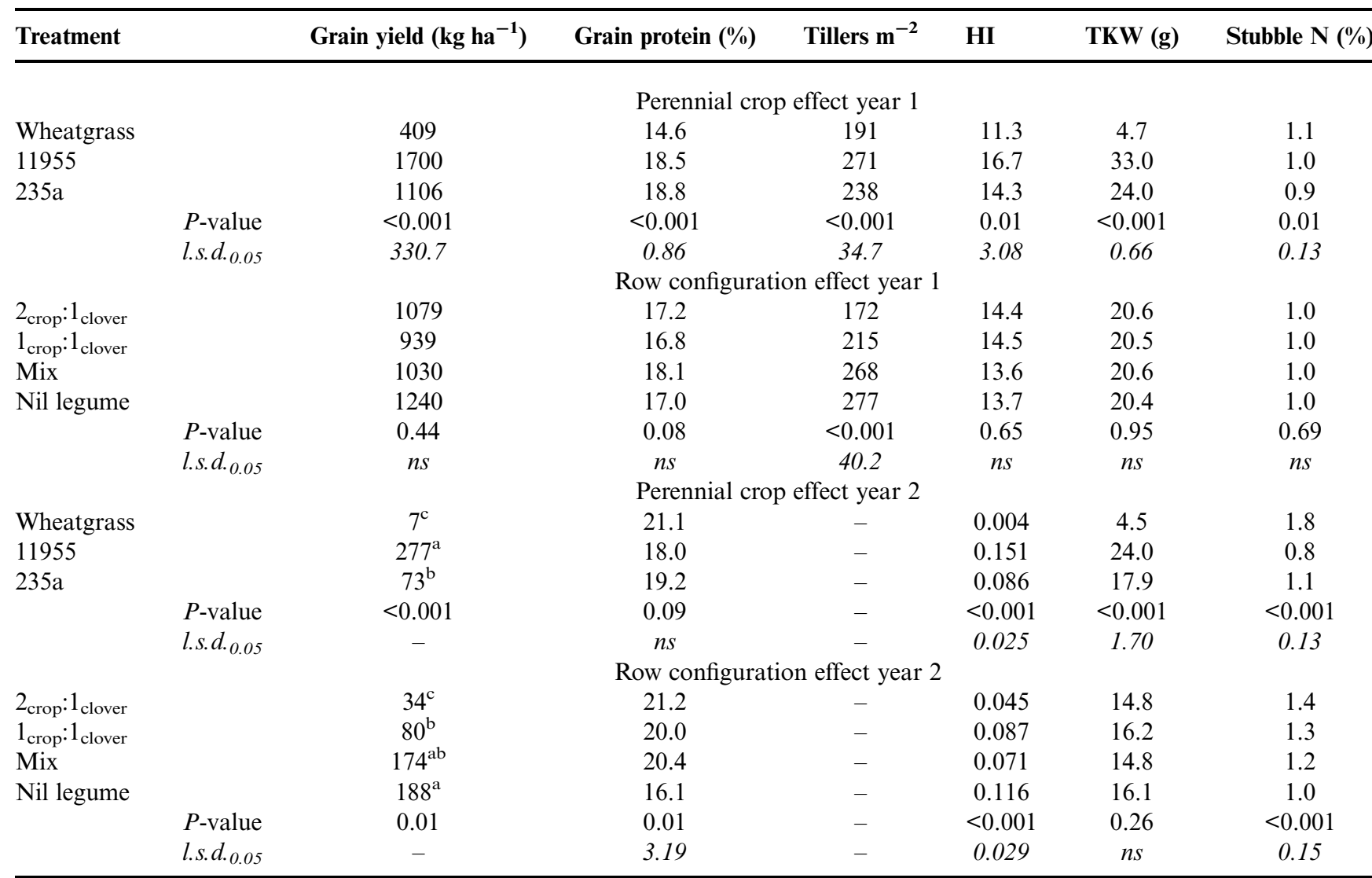

Non-significant differences at $P=0.05$ are marked 'ns'. Values followed by a superscript letter have been back-transformed; values followed by the same letter are not significantly different at $P=0.05$.

larger kernel size than the intermediate wheatgrass. This is consistent with previous field experience (Hayes et al., 2012). However, the hybrid lines were less persistent than the wheatgrass, and generally less persistent than previously observed at the same Cowra location (Hayes et al., 2012; Larkin et al., 2014). Undoubtedly, the drier seasonal conditions experienced during the current experiment contributed to this outcome.

An unavoidable challenge of conducting agronomy research with perennial wheat derivatives is the fact that breeding is ongoing and no commercial cultivars are yet available for the establishment of field experiments. Line 11955 was included in the current experiment as it was previously shown to have the highest year 1 grain yield and also a demonstrated capacity to persist beyond $1 \mathrm{yr}$ (Larkin et al., 2014). Line 235a was also among the most persistent of the hybrid derivatives evaluated in the target environment (Larkin et al., 2014). The wheatgrass line, CPI148055, was selected because it was the most persistent of the previously tested intermediate wheatgrass lines at this location, and had among the best grain quality attributes of the intermediate wheatgrasses (Hayes et al., 2012). More advanced breeding lines of intermediate wheatgrass and wheat $\times$ wheatgrass derivatives may now exist (DeHaan et al., 2013), but at the time of initiating the current experiment, newer lines had not yet undergone agronomic evaluation in Australia. Continued progress in germplasm development will undoubtedly bring elite germplasm to market in the coming decades (Cox et al., 2010; Larkin et al., 2014), but until then researchers are forced to work with analog crops, or as in this case, genotypes that are known to be insufficiently robust for commercial deployment. With this in mind, the relative differences between treatments become more important than absolute yields.

Establishment density of all perennial crops decreased when sown in the $2_{\text {crop }}: 1_{\text {clover }}$ and $1_{\text {crop }}: 1_{\text {clover }}$ configurations compared with the mix and nil legume treatments, despite being sown at the same seeding rate on an area basis. The sowing regimes meant that for a given perennial crop type, seeding rates per drill row increased by $60 \%$ in the $\left(2_{\text {crop }}: 1_{\text {clover }}\right)$ treatment and doubled in the $\left(1_{\text {crop }}: 1_{\text {clover }}\right)$ treatment, compared with where perennial crop seed was sown in every drill row. Reductions in plant populations have also been observed in a range of conventional grain crops when moving to wider row spacings due to an increase in seeding density within the drill row (Scott et al., 2013). The decrease in crop population 


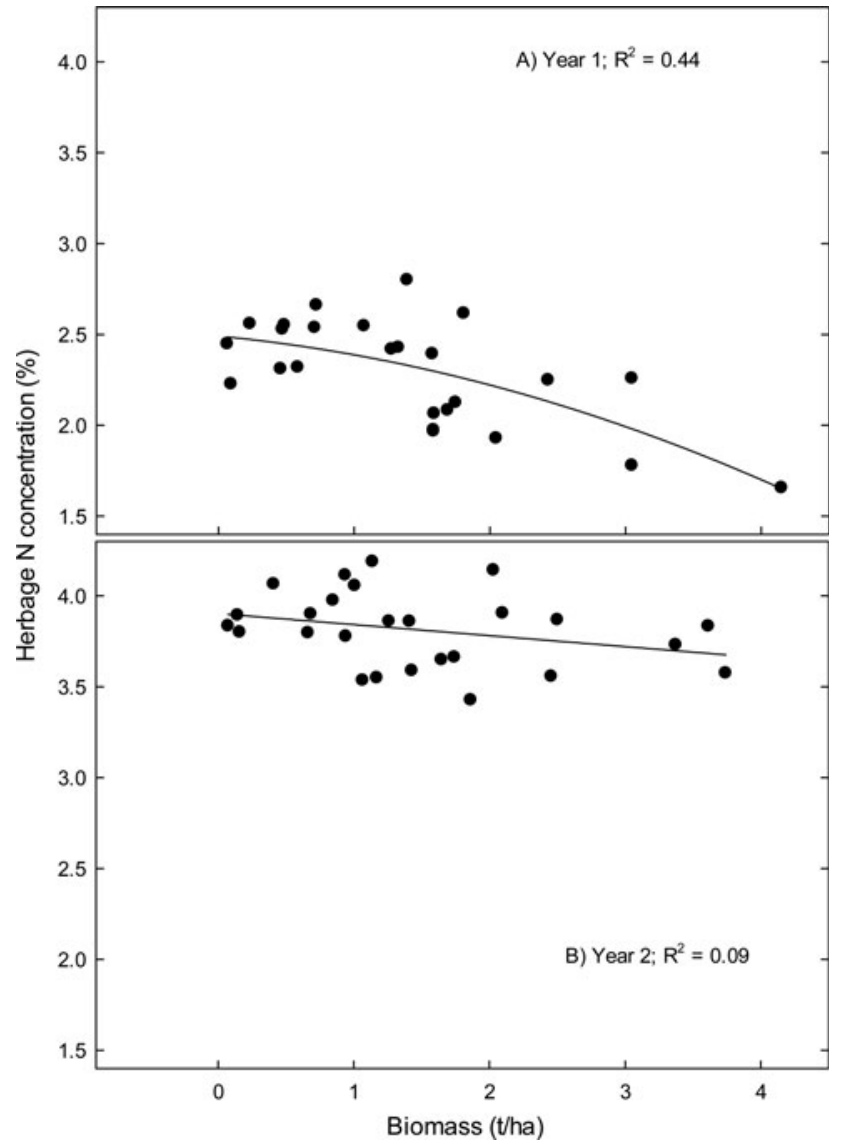

Figure 1. The relationship between subterranean clover biomass and shoot $\mathrm{N}$ concentration in spring year 1 and winter year 2 .

may be due to increased intraspecific competition for resources such as water early in seedling development, as suggested by Amjad and Anderson (2006) referring to a dry sandy environment of the Western Australian wheatbelt, but may also potentially be associated with compounds released from germinating seeds which inhibit the development of neighboring seedlings (Linhart, 1976). Our data suggest that some reduction in seeding rates may be possible when seed is concentrated in fewer drill rows, but the extent of the reduction possible before plant densities decline requires further refinement.

Increased seedling density in the mix and nil legume treatments led to improved perennial crop productivity in year 1, suggesting that at lower densities the perennial crops were unable to fully utilize available resources. To use $235 \mathrm{a}$ as an example, average seedling density was reduced by $20 \%$ in the $2_{\text {crop }}: 1_{\text {clover }}$ and $1_{\text {crop }}: 1_{\text {clover }}$ compared with the average of the mix and nil legume treatments and perennial crop biomass production observed in spring of year 1 was also reduced by a corresponding amount $(22 \%)$ between those same treatments. In relatively high-yielding environments, such as Cowra, yield is maximized through rapid groundcover by a newly sown crop, which maximizes the capture of light and minimizes evaporation of water from the soil surface (Scott et al., 2013). However, excluding the crop from some drill rows inhibits the ability of the crop to achieve complete canopy cover. With drill rows $0.25 \mathrm{~m}$ apart, the spacing between perennial crop rows was $0.50 \mathrm{~m}$ where the perennial crop was excluded from the intervening drill row and as observed, the perennial crop had relatively little capacity to compensate.

The inability for the perennial crop to compensate and fill the void left by the intervening row was exactly the reason for adopting this strategy when the objective was to facilitate greater legume survival within the perennial crop canopy. While perennial crop productivity was important, it was total productivity, in this case perennial crop plus legume, which determined the overall resource-use efficiency of the system. Total above-ground biomass was significantly less in the wheatgrass nil legume treatment in year 1 , reflecting the low productivity of wheatgrass in the establishment year. In year 2 biomass accumulation in the nil legume treatment for each perennial crop was numerically lower than all other treatments, although not all differences were significant $(P>0.05)$. The change from years 1 to 2 suggests a relative abundance of available resources such as $\mathrm{N}$ in the establishment year and highlights the importance of running these types of experiments over several years. The increase in clover $\mathrm{N}$ content in year 2 compared with year 1 despite seemingly high initial soil $\mathrm{N}$ values is likely explained by the reduced biomass (average $1.1 \mathrm{t} \mathrm{ha}^{-1}$ ) of clover in year 2 compared with year $1\left(1.5 \mathrm{tha}^{-1}\right)$, as well as the fact that clover herbage analysis in year 2 was conducted following a winter sampling rather than in spring.

The diversion of resources away from the perennial crop into the production of a forage legume has ramifications for grain production enterprises. In the current study, grain yield was always numerically higher in the nil legume treatments. It remains to be seen whether this holds true over a longer period. The profitability of perennial cropping systems based on crop-legume mixtures is enhanced by substantially reduced $\mathrm{N}$-fertilizer costs, but may also be reliant upon being able to utilize the noncrop biomass, such as through grazing. This is similar to existing cropping systems utilized in Australia and elsewhere, which already integrate grazing livestock and conventional crop production (Bell and Moore, 2012). Using perennial crop biomass for biofuel may also be a feasible option in some locations (Boehmel et al., 2008). An alternative approach would be to substitute the forage legume with a crop legume and harvest both components for grain (Jensen, 1996). However, in a perennial cropping system it is difficult to envisage how the legume component might be retained in the absence of inter-row disturbance and resowing annually to re-establish the legume, unless viable perennial legume crops are developed. There would also be challenges in finding compatible crops that mature at a similar time to aid harvest (Weik et al., 2002). The advantages of the forage legume option used here is that it was self-regenerating, and 
Table 6. Nitrogen concentration (\%), shoot and total plant $\mathrm{N}\left(\mathrm{kg} \mathrm{N} \mathrm{ha}^{-1}\right)$, and estimates of the proportion (\%) and total amounts of $\mathrm{N}_{2}$ fixed ( $\mathrm{kg} \mathrm{N} \mathrm{ha}^{-1}$ ) by subterranean clover in spring year 1 and winter year 2 when grown in mixtures with three perennial crop types in either mixed rows (mix), in alternate rows $\left(1_{\text {crop }}: 1_{\text {clover }}\right)$ or in a ratio of 2 rows of perennial crop: 1 row of clover $\left(2_{\text {crop }}: 1_{\text {clover }}\right)$.

\begin{tabular}{|c|c|c|c|c|}
\hline \multirow[b]{2}{*}{ Perennial crop } & & \multicolumn{3}{|c|}{ Row configuration } \\
\hline & & $2_{\text {crop }}: 1_{\text {clover }}$ & $1_{\text {crop }}: 1_{\text {clover }}$ & Mix \\
\hline & & \multicolumn{3}{|c|}{ Subterranean clover $\mathrm{N}$ concentration year $1(\%)$} \\
\hline \multicolumn{2}{|l|}{ Wheatgrass } & 2.09 & 1.90 & 2.21 \\
\hline 11955 & & 2.49 & 2.48 & 2.45 \\
\hline \multirow[t]{3}{*}{$235 \mathrm{a}$} & & 2.14 & 2.61 & 2.38 \\
\hline & \multirow[t]{2}{*}{ l.s.d.0.05 } & \multicolumn{3}{|c|}{0.355} \\
\hline & & \multicolumn{3}{|c|}{ Year 1 legume shoot $\mathrm{N}\left(\mathrm{kg} \mathrm{N} \mathrm{ha}^{-1}\right)$} \\
\hline Wheatgrass & & 33 & 45 & 46 \\
\hline 11955 & & 26 & 11 & 2 \\
\hline \multirow[t]{3}{*}{$235 \mathrm{a}$} & & 42 & 40 & 12 \\
\hline & l.s.d.0.05 & \multicolumn{3}{|c|}{12.3} \\
\hline & & \multicolumn{3}{|c|}{ Year 1 total (shoot + calculated root) legume $\mathrm{N}\left(\mathrm{kg} \mathrm{N}^{-1}\right)$} \\
\hline Wheatgrass & & 57 & 78 & 79 \\
\hline 11955 & & 44 & 19 & 3 \\
\hline \multirow[t]{3}{*}{$235 \mathrm{a}$} & & 72 & 68 & 21 \\
\hline & l.s.d.0.05 & & 36.7 & \\
\hline & & \multicolumn{3}{|c|}{ Year $1 \mathrm{~N}$ fixed $(\%)$} \\
\hline Wheatgrass & & 26 & 22 & 22 \\
\hline 11955 & & 22 & 29 & 38 \\
\hline \multirow[t]{3}{*}{$235 \mathrm{a}$} & & 21 & 24 & 17 \\
\hline & l.s.d.0.05 & & $n s$ & \\
\hline & & \multicolumn{3}{|c|}{ Year 1 total $\mathrm{N}$ fixed $\left(\mathrm{kg} \mathrm{N} \mathrm{ha}^{-1}\right)$} \\
\hline Wheatgrass & & 10 & 21 & 15 \\
\hline 11955 & & 9 & 5 & 1 \\
\hline \multirow[t]{3}{*}{$235 \mathrm{a}$} & & 14 & 17 & 5 \\
\hline & \multirow[t]{2}{*}{ l.s.d.0.05 } & \multirow{2}{*}{\multicolumn{3}{|c|}{$\begin{array}{c}n s \\
\text { Subterranean clover N concentration year } 2(\%)\end{array}$}} \\
\hline & & Subterrane & & \\
\hline Wheatgrass & & 3.99 & 3.69 & 3.66 \\
\hline 11955 & & 3.72 & 3.75 & 3.87 \\
\hline \multirow[t]{3}{*}{$235 \mathrm{a}$} & & 3.98 & 3.71 & 3.95 \\
\hline & \multirow{2}{*}{ l.s.d.0.05 } & \multirow{2}{*}{\multicolumn{3}{|c|}{ Year 2 legume shoot $\mathrm{N}\left(\mathrm{kg} \mathrm{N} \mathrm{ha}^{-1}\right)$}} \\
\hline & & & & \\
\hline Wheatgrass & & 27 & 67 & 47 \\
\hline 11955 & & 44 & 47 & 4 \\
\hline $235 \mathrm{a}$ & & 57 & 133 & 57 \\
\hline & l.s.d.0.05 & & 34.6 & \\
\hline & & Year 2 tota & root) legun & \\
\hline Wheatgrass & & 46 & 115 & 81 \\
\hline 11955 & & 76 & 81 & 7 \\
\hline $235 \mathrm{a}$ & & 98 & 228 & 98 \\
\hline & l.s.d.0.05 & & 59.5 & \\
\hline & & Year $2 \mathrm{~N}$ fi & & \\
\hline Wheatgrass & & 86 & 80 & 63 \\
\hline 11955 & & 76 & 71 & 80 \\
\hline $235 \mathrm{a}$ & & 78 & 73 & 74 \\
\hline & l.s.d. ${ }_{0.05}$ & & $n s$ & \\
\hline & & Year 2 tota & & \\
\hline Wheatgrass & & $37^{\mathrm{b}}$ & $91^{\mathrm{ab}}$ & $44^{\mathrm{b}}$ \\
\hline 11955 & & $55^{\mathrm{b}}$ & $56^{\mathrm{ab}}$ & $5^{\mathrm{c}}$ \\
\hline $235 a$ & & $67^{\mathrm{ab}}$ & $165^{\mathrm{a}}$ & $44^{\mathrm{b}}$ \\
\hline
\end{tabular}

Non-significant differences at $P=0.05$ are marked 'ns'. Values followed by a superscript letter have been back-transformed; values followed by the same letter are not significantly different at $P=0.05$. 
Table 7. Nitrogen concentration ( $\%)$ in herbage of three perennial crop types grown in nil legumes or in or with subterranean clover in mixed rows (Mix), in alternate rows $\left(1_{\text {crop }}: 1_{\text {clover }}\right)$ or in a ratio of 2 rows of perennial crop: 1 row of clover $\left(2_{\text {crop }}: 1_{\text {clover }}\right)$, sampled in October year 1 and July year 2.

\begin{tabular}{|c|c|c|c|c|}
\hline \multirow[b]{2}{*}{ Perennial crop } & \multicolumn{4}{|c|}{ Row configuration } \\
\hline & $2_{\text {crop }}: 1_{\text {clover }}$ & $1_{\text {crop }}: 1_{\text {clover }}$ & Mix & Nil legume \\
\hline & \multicolumn{4}{|c|}{ Year 1} \\
\hline Wheatgrass & 2.29 & 2.11 & 2.19 & 2.14 \\
\hline 11955 & 1.62 & 1.57 & 1.54 & 1.52 \\
\hline $235 \mathrm{a}$ & 1.50 & 1.52 & 1.59 & 1.48 \\
\hline & \multicolumn{4}{|c|}{$\begin{array}{l}0.182 \\
\text { Year } 2\end{array}$} \\
\hline Wheatgrass & 3.08 & 3.49 & 3.54 & 2.72 \\
\hline 11955 & 2.51 & 2.06 & 2.21 & 2.02 \\
\hline $235 \mathrm{a}$ & 3.33 & 3.05 & 3.61 & 3.45 \\
\hline & \multicolumn{4}{|c|}{0.734} \\
\hline
\end{tabular}

Table 8. Calculated $\mathrm{N}$ accumulation $\left(\mathrm{kg} \mathrm{N} \mathrm{ha}^{-1}\right)$ in perennial crop biomass and grain at harvest in years 1 and 2 .

\begin{tabular}{|c|c|c|c|c|}
\hline Treatment & & Grain N & Stubble N & Total $\mathbf{N}$ \\
\hline \multicolumn{5}{|c|}{ Year 1} \\
\hline Wheatgrass & & 10 & 32 & 42 \\
\hline 11955 & & 55 & 68 & 123 \\
\hline \multirow[t]{3}{*}{$235 \mathrm{a}$} & & 36 & 58 & 94 \\
\hline & $P$-value & $<0.001$ & $<0.001$ & $<0.001$ \\
\hline & l.s.d. 0.05 & 10.2 & 9.1 & 7.7 \\
\hline $2_{\text {crop }}: 1_{\text {clover }}$ & & 34 & 51 & 85 \\
\hline $1_{\text {crop }}: 1_{\text {clover }}$ & & 29 & 42 & 71 \\
\hline Mix & & 33 & 57 & 90 \\
\hline \multirow[t]{4}{*}{ Nil legume } & & 39 & 60 & 99 \\
\hline & $P$-value & 0.43 & 0.01 & $<0.001$ \\
\hline & l.s.d.0.05 & $n s$ & 10.5 & 8.9 \\
\hline & & Year 2 & & \\
\hline Wheatgrass & & $<1$ & 37 & 37 \\
\hline 11955 & & 8 & 11 & 19 \\
\hline \multirow[t]{3}{*}{$235 a$} & & 2 & 7 & 9 \\
\hline & $P$-value & $<0.001$ & $<0.001$ & $<0.001$ \\
\hline & l.s.d.0.05 & 1.9 & 5.6 & 6.1 \\
\hline $2_{\text {crop }}: 1_{\text {clover }}$ & & 1 & 19 & 20 \\
\hline $1_{\text {crop }}: 1_{\text {clover }}$ & & 3 & 12 & 14 \\
\hline Mix & & 5 & 22 & 27 \\
\hline \multirow[t]{3}{*}{ Nil legume } & & 6 & 20 & 26 \\
\hline & $P$-value & $<0.001$ & 0.02 & 0.004 \\
\hline & l.s.d.0.05 & 2.2 & 6.4 & 7.1 \\
\hline
\end{tabular}

ns $=$ differences not significant at $P=0.05$.

compared with a companion crop legume, more likely to result in a net return of fixed $\mathrm{N}$ to the system due to a large proportion of $\mathrm{N}$ exported in the legume grain following harvest (Peoples et al., 2001).

Grain protein in the current study was not affected by sowing configuration in year 1 suggesting adequate $\mathrm{N}$ and water resources were available for grain production in that year, but in year 2 grain protein was significantly lower in the nil legume treatments compared with where legumes had been included in the mix. The reduction in grain protein was not fully explained by the increase in grain yield in the nil legume treatments, suggesting that the presence of legumes increased $\mathrm{N}$-availability to the perennial crop. The other novel finding was the significantly greater $\mathrm{N}$ content of the wheatgrass stubble compared with stubble of the hybrid perennial crops. At $1.8 \% \mathrm{~N}$ (equivalent to $10.1 \%$ protein) in year 2 it would seem wheatgrass stubble in particular has potential to add significant value to grazing enterprises following harvest. By comparison, other perennial forage grasses grown in a similar environment have been shown to have a protein content of $6-9 \%$ at that time of year (Hayes et al., 2010). Further research on the grazing value of perennial crops is warranted. Stubble N (protein) content was not affected by row configuration in year 1 , but in year 2 was greater in the $2_{\text {crop }}: 1_{\text {clover }}$ treatment and lowest in the nil legume treatment where $\mathrm{N}$ addition was minimal.

\section{Forage legume growth and $\mathrm{N}_{2}$ fixation}

Although subterranean clover seeding rate was the same on an area basis for all except the nil legume treatments, seeding density within the drill row was double and $167 \%$ greater in the $1_{\text {crop }}: 1_{\text {clover }}$ and 2 crop $: 1_{\text {clover }}$ treatments, respectively, compared with the mix treatments. This perhaps explains why establishment density of subterranean clover in year 1 was unaffected by perennial crop type, but was significantly lower in the $2_{\text {crop }}: 1_{\text {clover }}$ treatment compared with where it was sown in mixed rows. The combined density of wheat and subterranean clover was greatest in the mix compared with other spatial configuration treatments and greatest in the 11955 compared with other perennial crop treatments, which is where competition for resources might be presumed to be greatest in year 1 . Indeed, subterranean 
clover biomass in spring in year 1 was lowest where it was sown in a mixed row configuration with 11955, and regeneration in year 2 was also lowest in the 11955 treatment and lower in the mix compared with the $1_{\text {crop }}: 1_{\text {clover }}$ treatments. It is interesting that regeneration in the $2_{\text {crop }}: 1_{\text {clover }}$ treatments in year 2 was significantly less than in the $1_{\text {crop- }}$ $: 1_{\text {clover }}$ treatment and similar to that observed in the mix treatments, particularly considering total plant density (perennial crop plus subterranean clover) was significantly higher in the mix treatments in year 1 . This result is likely explained by the lower subterranean clover densities in year 1 leading to lower regeneration in the $2_{\text {crop- }}$ $: 1_{\text {clover }}$ treatments. Donald (1951) described the relative plasticity of subterranean clover growing in a pure sward and how maximum yields, including seed yields, could be achieved at relatively low plant densities. The plant density in all treatments in the current experiment (40-56 plants $\mathrm{m}^{-2}$ ) were well below the minimum density ( 296 plants $\mathrm{m}^{-2}$ ) observed by Donald to achieve maximum yields in pure subterranean clover swards. There appears to be few established benchmarks for minimum subterranean clover density required for optimal levels of production in mixed swards with perennial species. Values in the current experiment appear lower than was achieved by Dear et al. (2001) in a similar environment where subterranean clover grown in mixtures with perennial forage species regenerated at densities of 66-96 plants $\mathrm{m}^{-2}$. It would seem subterranean clover density at $40-90$ plants $\mathrm{m}^{-2}$ is too low for adequate legume abundance and our study suggests a limit exists to the extent seeding density can be intensified within a smaller number of drill rows.

Subterranean clover biomass in year 2 remained lower in the 11955 mix treatment, presumably as a result of increased competition inhibiting the ability of subterranean clover to set seed in year 1, and in year 2 was generally higher in the $1_{\text {crop }}: 1_{\text {clover }}$ treatments. From the perspective of increasing annual legume composition of mixed swards, the $1_{\text {crop }}: 1_{\text {clover }}$ approach to sowing would seem to offer potential by providing benefits to legume production and regeneration compared with the mixed row configurations, without the negative effects on legume population observed in the more extreme $2_{\text {crop }}: 1_{\text {clover }}$ configuration. The lower incursion of weeds in the $1_{\text {crop }}: 1_{\text {clover }}$ treatment in year 2 provides additional encouragement that the alternate row configuration may present as a viable strategy to achieve a more balanced perennial crop/legume mixture than conventional approaches to sowing.

There was no effect of treatment on the clover's reliance upon $\mathrm{N}_{2}$ fixation for growth, although values were noticeably higher in year 2 (average $76 \%$ ) compared with year 1 $(25 \%)$. This was most likely due to the high levels of mineral $\mathrm{N}$ in the soil profile at the commencement of the experiment (Peoples et al., 2012). However, poor nodulation in year 1 attributable to the factory applied rhizobial inoculant as a seed coating has previously been reported to result in suboptimal nodulation of pasture legumes (Gemell et al., 2005) and, although not measured in the current study, cannot be ruled out as a factor contributing to the low rates of $\mathrm{N}_{2}$ fixation observed. Nitrogen concentration was also relatively low for subterranean clover in year 1, was negatively correlated with shoot biomass (Fig. 1), and the amount of shoot $\mathrm{N}$ fixed per tonne of shoot DM accumulated in all treatments $\left(<10 \mathrm{~kg} \mathrm{~N} \mathrm{t}^{-1} \mathrm{DM}\right.$; calculated from data in Tables 6 and 7) was less than the previously established benchmark of around $20 \mathrm{~kg} \mathrm{~N} \mathrm{t}^{-1} \mathrm{DM}$ (Unkovich et al., 2010; Peoples et al., 2012). All these indicators are consistent with a constraint to the $\mathrm{N}_{2}$ fixation process in year 1 .

Legume shoot biomass measured in the current study largely reflected legume abundance, with greater inputs of legume and fixed $\mathrm{N}$ observed in treatments with the highest legume content. This presents a paradox in developing viable and sustainable mixtures of perennial cereal crops and self-regenerating annual legumes in as much as mixtures with a strong legume component maximize $\mathrm{N}$ inputs to the cropping system, but also represent increased competition for the perennial crop. In the current study the $1_{\text {crop }}: 1_{\text {clover }}$ treatments provided promising compromises between reducing competition between species while maximizing legume composition and inputs of biologically fixed N. More research is required to further refine efficiencies and trade-offs in binary mixtures, especially as perennial crops become closer to commercial reality on a broad scale.

The $\mathrm{N}$ accumulated in the perennial crop above-ground biomass at maturity (42-123 $\mathrm{kg} \mathrm{N} \mathrm{ha}^{-1}$ ), and the component of that $\mathrm{N}$ subsequently removed in grain $(10-55 \mathrm{~kg}$ $\mathrm{N} \mathrm{ha}^{-1}$ ) generally exceeded the total amounts of $\mathrm{N}_{2}$ fixed by the legume in year $1\left(1-21 \mathrm{~kg} \mathrm{~N} \mathrm{ha}^{-1}\right)$. By contrast in year 2, the estimated inputs of fixed $\mathrm{N}$ by the clover would have been enough to meet the highest perennial crop demand for $\mathrm{N}$ observed $\left(40-92 \mathrm{~kg}\right.$ fixed $\mathrm{N} \mathrm{ha}^{-1}$ in wheatgrass treatments of $37 \mathrm{~kg} \mathrm{~N}^{-1}$ in wheatgrass biomass). The relatively low levels of $\mathrm{N}$ accumulated by the perennial crops and the low grain yields reflected the poor plant persistence over the dry summer and lower plant densities in year 2 . If it was assumed that a future perennial wheat crop would experience lower plant mortality rates and achieve similar levels of DM production and grain yields observed in year 1 in the current experiment (i.e., in the order of $120-130 \mathrm{~kg} \mathrm{~N} \mathrm{ha}^{-1}$ accumulated in above-ground biomass) over a period of several years, then the average inputs of fixed $\mathrm{N}$ measured in the second year of the experiment (average $63 \mathrm{~kg}$ fixed $\mathrm{N} \mathrm{ha}^{-1}$ ) would not fully balance the perennial crop's $\mathrm{N}$ requirements.

However, given that $55-76 \%$ of the $\mathrm{N}$ accumulated would remain in the stubble of the perennial plant and could subsequently be available either to decompose on the soil surface, or be remobilized internally to support summer survival and future organ growth, the present study suggests that perennial crops could feasibly source 
much of their $\mathrm{N}$ requirement from a companion legume such as subterranean clover. This is particularly true in the alternate row configuration where total inputs of fixed $\mathrm{N}$ averaged over $100 \mathrm{~kg} \mathrm{~N} \mathrm{ha}^{-1}$. Certainly the annual inputs of fixed $\mathrm{N}$ might be sufficient to balance the $\mathrm{N}$ removed each year in 1.5-2.0 $\mathrm{t}$ of grain $\mathrm{ha}^{-1}$ (in the order of $50-60 \mathrm{~kg} \mathrm{~N} \mathrm{ha}^{-1}$ ). This will be dependent upon the efficient cycling of $\mathrm{N}$ between the legume and the perennial crop, and on achieving synchrony of $\mathrm{N}$ supply and demand between the legume and perennial crop (Crews and Peoples, 2005; Crews et al., 2016). Modest and strategic applications of fertilizer $\mathrm{N}$ during peak periods of perennial crop $\mathrm{N}$ demand may be required to ensure the perennial crop requirements can be met.

Crews et al. (2016) also note the need for N-inputs to exceed harvest- $\mathrm{N}$ replacement requirements in order to meet additional $\mathrm{N}$ needs of an agro-ecosystem with an aggrading soil organic matter pool, as would be expected under early generation perennial crops. Further research is required to determine whether the spatial separation of perennial crop and legume plants by single species row configurations will pose an obstacle to a perennial crop accessing $\mathrm{N}$ provided by a companion legume. Root architecture is acknowledged as an important factor contributing to below-ground $\mathrm{N}$-transfer with fibrous-rooted species seemingly providing an advantage in scavenging $\mathrm{N}$ from neighboring legumes (PirhoferWalzl et al., 2012). Proximity of the grass root to the legume root would also no doubt be an important factor. Grazing of forage by livestock is thought to assist with $\mathrm{N}$-cycling by increasing the rate of $\mathrm{N}$-turnover, particularly of above-ground components returned to the soil in a relatively short period of time in forms largely available to plants. However, grazing livestock are likely to cause undue concentration of $\mathrm{N}$ in localized areas and introduce variation in nutrient status across a field (Hilder, 1966). Although the majority of the herbage $\mathrm{N}$ consumed will be excreted as urine and faeces, livestock such as sheep represent a sink for nutrients such as $\mathrm{N}$ and some $\mathrm{N}$ losses from urine patches would also likely occur (Virgona et al., 2006; Peoples et al., 2012). The plots in the current study were relatively small and grazing was typically intensive with large numbers of sheep on a small area. We therefore anticipate that the distribution of nutrients following grazing was perhaps more even than might be expected in more extensively grazed systems.

Further research is required to understand the $\mathrm{N}$ requirements and dynamics of a perennial crop maintaining roots and other survival structures year-round. For example, under controlled conditions and in the absence of grazing, the perennial forage grass, phalaris (Phalaris aquatica $\mathrm{L}$.), showed no real loss of $\mathrm{N}$ from the plant as it matured, but a 'downward migration' of $\mathrm{N}$ from the herbage to the basal portion of the stem and to the root system was observed (Richardson et al., 1932). It is unknown whether a perennial grain crop would respond similarly to a perennial forage grass, given the known importance of adequate $\mathrm{N}$-translocation to the maturing seed head to support yield and grain quality. Other perennial forage grasses such as cocksfoot (orchardgrass; Dactylis glomerata L.) are known to shed and regrow a large proportion of their root structure from year to year (Ridley and Simpson, 1994), which may result in increased net N-loss from the plant unless it can efficiently translocate $\mathrm{N}$ to remaining live structures. Most studies of N remobilisation within a plant (e.g., Ourry et al., 1988) have focused on forage species which may have substantially different internal $\mathrm{N}$-demands than a perennial crop grown for grain.

\section{Future research priorities}

This initial experiment provides confidence in the merit of further refining strategies to grow perennial cereal crops in mixtures with legumes. Our investigation suggests that $\mathrm{N}$ inputs from a companion forage legume could balance $\mathrm{N}$ requirements of perennial cereals yielding $1.5-2.0 \mathrm{t} \mathrm{ha}^{-1}$ grain, annually. Further development of perennial wheat germplasm is necessary to improve longevity of the hybrid wheat $\times$ wheatgrass derivatives for future testing. In the meantime, future studies should target environments in which perennial wheat longevity is assured to maximize the opportunity to monitor succession in perennial wheat/legume mixtures over a longer period. It would seem that existing perennial wheat material would benefit by being tested in environments where summer temperatures are lower, and humidity and summer rainfall is higher than at Cowra. An environment similar to the second environment described in the initial evaluation of perennial wheat material in Australia, Woodstock NSW, might perhaps be a more suitable climate (Hayes et al., 2012); however, there will always be the risk of periodic drought in any rainfed cropping system.

Much remains unknown in this novel field of perennial crop/legume mixtures research. The choice of companion legume obviously warrants further investigation, and will likely be informed by the range of adapted legume options available in different environments. Maintaining an adequate legume content remains a challenge in perennialbased pasture swards (Davies, 2001; Dear et al., 2001), and characteristics particular to perennial crops, such as the perceived high $\mathrm{N}$ demand to fill grain at the end of spring, promise to present additional challenges to be overcome. Alternative spatial configurations at sowing show potential for managing competition dynamics between species, as was observed by the superior legume composition and lower weed incursion in our alternate row $\left(1_{\text {crop }}: 1_{\text {clover }}\right)$ treatments. The same approach is showing some promise in better managing legume composition in perennial-based pasture swards for grazing (Butler et al., 2011; Sandral et al., 2015). Aspects of our spatial configurations could be further explored, such as 
to identify the optimal row spacing and the optimal seedling density within a drill row. Our data suggest that opportunity exists to reduce sowing rates in some spatial configurations. Again, these factors will likely be impacted by the choice of companion legume. Arguably, the highest priority for further research remains in better understanding the internal $\mathrm{N}$ allocation and demands of a perennial crop. To know how much and when $\mathrm{N}$ is required will enable future researchers to identify an optimal legume content within a perennial crop stand and to further develop strategies to achieve the desired legume composition to meet perennial crop $\mathrm{N}$ demands.

Acknowledgements. This experiment was initiated with financial support from the Grains Research and Development Corporation through their EverCrop initiative-perennial plants for cropping environments (project number CSA00044). The authors gratefully acknowledge Sue Langfield (NSW DPI) for technical assistance monitoring the field experiment and Laura Goward (CSIRO) for assistance with laboratory analysis. We also gratefully acknowledge Melinda Merrill and the Estes Institute, Estes Park, Colorado USA, for sponsoring the 'New Roots for Ecological Intensification' meeting in 2014 which led to the production of this paper.

\section{References}

Amjad, M. and Anderson, W.K. 2006. Managing yield reductions from wide row spacing in wheat. Australian Journal of Experimental Agriculture 46:1313-1321.

AOCS 1995. Official ethods and recommended practices of the AOCS, 6th edition. In AOCS Official Method Ba 4e-93; Generic combustion method for determination of crude protein. American Oilseed Chemist Society. Available at Web site https://aocs.personifycloud.com/PersonifyE Business/Default.aspx?TabID=251\&productId=111449.

Bell, L.W. and Moore, A.D. 2012. Integrated crop-livestock systems in Australian agriculture: Trends, drivers and implications. Agricultural Systems 111:1-12.

Boehmel, C., Lewandowski, I., and Claupein, W. 2008. Comparing annual and perennial energy cropping systems with different management intensities. Agricultural Systems 96:224-236.

Boschma, S.P., Lodge, G.M., and Harden, S. 2010. Seedling competition of lucerne in mixtures with temperate and tropical pasture species. Crop and Pasture Science 61(5):411-419.

Butler, T.J., Stein, J.D., Interrante, S.M. and Malinowski, D.P. 2011. Novel approaches to establishing alfalfa-tall fescue pastures in the Southern Great Plains. Forage and Grazinglands 9 (1). doi: 10.1094/FG-2011-0725-1001-RS.

Cox, T.S., Van Tassel, D.L., Cox, C.M., and DeHaan, L.R. 2010. Progress in breeding perennial grains. Crop and Pasture Science 61(7):513-521.

Crews, T.E., Blesh, J., Culman, S.W., Hayes, R.C., Jensen, E.S., Mack, M.C., Peoples, M.B., and Schipanski, M.E. 2016. Going where no grains have gone before: From early to mid-succession. Agriculture, Ecosystems \& Environment 223:223-238.

Crews, T.E. and DeHaan, L.R. 2015. The strong perennial vision: A response. Agroecology and Sustainable Food Systems 39:500-515.
Crews, T.E. and Peoples, M.B. 2005. Can the synchrony of nitrogen supply and crop demand be improved in legume and fertiliser-based ecosystems? A review. Nutrient Cycling in Agroecosystems 72:101-120.

Davies, A. 2001. Competition between grasses and legumes in established pastures. In P.G. Tow and A. Lazenby (eds) Competition and Succession in Pastures. CABI Publishing, New York, USA. p. 63-84.

Dear, B.S., Cocks, P.S., Wolfe, E.C., and Collins, D.P. 1998. Established perennial grasses reduce the growth of emerging subterranean clover seedlings through competition for water, light, and nutrients. Australian Journal of Agricultural Research 49(1):41-52.

Dear, B.S., Peoples, M.B., Cocks, P.S., Swan, A.D., and Smith, A.B. 1999. Nitrogen fixation by subterranean clover (Trifolium subterraneum L.) growing in pure culture and in mixtures with varying densities of lucerne (Medicago sativa L.) or phalaris (Phalaris aquatica L.). Australian Journal of Agricultural Research 50(6):1047-1058.

Dear, B.S., Sandral, G.A., Virgona, J.M., and Swan, A.D. 2004. Yield and grain protein of wheat following phased perennial grass, lucerne, and annual pastures. Australian Journal of Agricultural Research 55(7):775-785.

Dear, B.S., Virgona, J.M., Sandral, G.A., Swan, A.D., and Orchard, B.A. 2001. Effect of companion perennial grasses and lucerne on seed yield and regeneration of subterranean clover in two wheatbelt environments. Australian Journal of Agricultural Research 52(10):973-983.

DeHaan, L.R., Wang, S., Larsen, S.R., Cattani, D.J., Zhang, X., and Viinanen, T. 2013. Current efforts to develop perennial wheat and domesticate Thinopyrum intermedium as a perennial grain. In C. Batello, L. Wade, S. Cox, N. Pogna, A. Bozzini and J. Choptiany (eds) Perennial Crops for Food Security, 28-30 August, Food and Agriculture Organization of the United Nations, Rome, Italy. p. 72-89.

Donald, C. 1951. Competition among pasture plants. I. Intraspecific competition among annual pasture plants. Australian Journal of Agricultural Research 2(4):355-376.

Dunin, F. and Passioura, J. 2006. Prologue: Amending agricultural water use to maintain production while affording environmental protection through control of outflow. Australian Journal of Agricultural Research 57(3):251-255.

Gemell, L.G., Hartley, E.J., and Herridge, D.F. 2005. Point-ofsale evaluation of preinoculated and custom-inoculated pasture legume seed. Australian Journal of Experimental Agriculture 45(3):161-169.

Gomiero, T., Pimentel, D., and Paoletti, M.G. 2011. Is there a need for a more sustainable agriculture? Critical Reviews in Plant Sciences 30(1-2):6.

Harper, J.L. 1977. Population Biology of Plants. Academic Press, London.

Hayes, R.C., Dear, B.S., Li, G.D., Virgona, J.M., Conyers, M. K., Hackney, B.F., and Tidd, J. 2010. Perennial pastures for recharge control in temperate drought-prone environments. Part 1: Productivity, persistence and herbage quality of key species. New Zealand Journal of Agricultural Research 53(4):283-302.

Hayes, R.C., Newell, M.T., DeHaan, L.R., Murphy, K.M., Crane, S., Norton, M.R., Wade, L.J., Newberry, M., Fahim, M., Jones, S.S., Cox, T.S., and Larkin, P.J. 2012. Perennial cereal crops: An initial evaluation of wheat derivatives. Field Crops Research 133:68-89. 
Hilder, E.J. 1966. Rate of turnover of elements in soils: The effects of stocking rate. Wool Technology and Sheep Breeding 13(2):11-16.

Isbell, R.F. 1996. The Australian Soil Classification. CSIRO Publishing, Melbourne.

Jensen, E.S. 1996. Grain yield, symbiotic N2 fixation and interspecific competition for inorganic $\mathrm{N}$ in pea-barley intercrops. Plant and Soil 182(1):25-38.

Jolliffe, P.A. 1997. Are mixed populations of plant species more productive than pure stands? Oikos 80(3):595-602.

Larkin, P.J., Newell, M.T., Hayes, R.C., Aktar, J., Norton, M. R., Moroni, S.J., and Wade, L.J. 2014. Progress in developing perennial wheats for grain and grazing. Crop and Pasture Science 65(11):1147-1164.

Linhart, Y.B. 1976. Density-dependant seed germination strategies in colonizing versus non-colonizing plant species. Journal of Ecology 64(1):375-380.

Lodge, G. and Gleeson, A. 1984. A comparison of methods of estimating lucerne population for monitoring persistence. Australian Journal of Experimental Agriculture 24(125): 174-177.

McNeill, A.M., Zhu, C., and Fillery, I.R.P. 1997. Use of in situ ${ }^{15} \mathrm{~N}$-labelling to estimate the total below-ground nitrogen of pasture legumes in intact soil-plant systems. Australian Journal of Agricultural Research 48(3):295-304.

Ourry, A., Boucaud, J., and Salette, J. 1988. Nitrogen mobilization from stubble and roots during re-growth of defoliated perennial ryegrass. Journal of Experimental Botany 39(203):803-809.

Peoples, M.B., Bowman, A.M., Gault, R.R., Herridge, D.F., McCallum, M.H., McCormick, K.M., Norton, R.M., Rochester, I.J., Scammell, G.J., and Schwenke, G.D. 2001. Factors regulating the contributions of fixed nitrogen by pasture and crop legumes to different farming systems of eastern Australia. Plant and Soil 228(1):29-41.

Peoples, M.B., Brockwell, J., Hunt, J.R., Swan, A.D., Watson, L., Hayes, R.C., Li, G.D., Hackney, B., Nuttall, J. G., Davies, S.L., and Fillery, I.R.P. 2012. Factors affecting the potential contributions of $\mathrm{N} 2$ fixation by legumes in Australian pasture systems. Crop and Pasture Science 63(9):759-786.

Picasso, V.D., Brummer, E.C., Liebman, M., Dixon, P.M., and Wilsey, B.J. 2011. Diverse perennial crop mixtures sustain higher productivity over time based on ecological complementarity. Renewable Agriculture and Food Systems 26(4): 317-327.

Pirhofer-Walzl, K., Rasmussen, J., Hogh-Jensen, H., Eriksen, J., Soegaard, K., and Rasmussen, J. 2012. Nitrogen transfer from forage legumes to nine neighbouring plants in a multi-species grassland. Plant and Soil 350:71-84.

Richardson, A.E.V., Trumble, H.C., and Shapter, R.E. 1932. The influence of growth stage and frequency of cutting on yield and composition of a perennial grass-Phalaris tuberosa. Commonwealth of Australia Council for Scientific and Industrial Research Bulletin No. 66.

Ridley, A.M. and Simpson, R.J. 1994. Seasonal development of roots under perennial and annual grass pastures. Australian Journal of Agricultural Research 45(5):1077-1087.

Sandral, G.A., Swan, A.D., Li, G.D., Goward, L., Peoples, M.B., and Hayes, R.C. 2015. Alternate row sowing: A novel approach to maintain sown species in mixed pasture swards. In T. Botwright Acuna, C. Moeller, D. Parsons and M. Harrison (eds). 'Building Productive, Diverse and Sustainable Landscapes' Proceedings of the 17th Australian Agronomy Conference. 21-24 September, Hobart, Tasmania http://www.agronomy2015.com.au/proceedings.

Scott, B.J., Martin, P., and Riethmuller, G.P. 2013. Row spacing of winter crops in broad scale agriculture in southern Australia. In Graham Centre Monograph No. 3: (Eds T Nugent and C Nicholls). NSW Department of Primary Industries, Orange. Available at www.grahamcentre.net.

Sleugh, B., Moore, K.J., George, R., and Brummer, E.C. 2000. Binary legume-grass mixtures improve forage yield, quality, and seasonal distribution. Agronomy Journal 92: 24-29.

Unkovich, M., Baldock, J., and Peoples, M. 2010. Prospects and problems of simple linear models for estimating symbiotic $\mathrm{N}_{2}$ fixation by crop and pasture legumes. Plant and Soil 329(1): 75-89.

Unkovich, M.J., Herridge, D.F., Peoples, M.B., Cadisch, G., Boddey, R.M., Giller, K.E., Alves, B., and Chalk, P.M. 2008. Measuring Plant-associated Nitrogen Fixation in Agricultural Systems. Australian Centre for International Agricultural Research Monograph No. 136, Canberra. p. 258.

Virgona, J.M., Gummer, F.A.J., and Angus, J.F. 2006. Effects of grazing on wheat growth, yield, development, water use, and nitrogen use. Australian Journal of Agricultural Research 57 (12):1307-1319.

Weik, L., Kaul, H.-P., Kubler, E., and Aufhammer, W. 2002. Grain yields of perennial grain crops in pure and mixed stands. Journal of Agronomy and Crop Science 188:342-349.

Wolfe, E.C. and Southwood, O.R. 1980. Plant productivity and persistence in mixed pastures containing lucerne at a range of densities with subterranean clover or phalaris. Australian Journal of Experimental Agriculture and Animal Husbandry 20(103):189-196. 